Diego Barragán-Martínez, MD

Ana Simarro-Díaz, MD

Patricia Calleja-Castaño, MD

Aurelio Hernández-Laín, MD

Ana Ramos-González, MD

Alberto Villarejo-Galende, MD

Neurol Neuroimmunol Neuroinflamm

2017;4:e319; doi: 10.1212/ NXI.0000000000000319

\section{DELAYED TACROLIMUS \\ LEUKOENCEPHALOPATHY, A RARE AND \\ REVERSIBLE CAUSE OF DEMENTIA \\ OPEN}

The immunosuppressant tacrolimus (FK506) is widely used in transplantation medicine. An acute leukoencephalopathy with clinical and radiologic features similar to posterior reversible encephalopathy syndrome (PRES) is a common side effect of tacrolimus, and usually develops within the first year of commencing treatment, ${ }^{1}$ but a delayed and chronic leukoencephalopathy has been reported rarely in the literature. We describe a patient who developed extensive chronic leukoencephalopathy with contrast enhancement, reversible after tacrolimus withdrawal.

Case report. A 68-year-old man with primary sclerosing cholangitis underwent liver transplantation in 2004. Prevention of graft rejection was initiated and the maintenance therapy was tacrolimus $1 \mathrm{mg}$ and mycophenolate $360 \mathrm{mg}$ BID. In 2014, 10 years later, he was transferred from an outside hospital for evaluation of 12-month progressive cognitive and functional decline. The patient did not have previous cognitive complaints, symptoms onset had been gradual, and the progression was rapid, developing over that time moderate dementia with frontal features and gait impairment requiring a wheelchair. His family reported a personality change with marked apathy and occasional impulsivity.

His Mini-Mental State Examination (MMSE) score was $14 / 30$, and neuropsychological testing revealed severe impairment of attention and executive functions, with moderate memory and visuospatial problems.

Brain MRI showed a diffuse leukoencephalopathy involving cerebral hemispheres and posterior fossa, with patchy multifocal contrast enhancement (figure, A-B). Spine MRI was normal.

Laboratory results were unremarkable and whole blood tacrolimus level was $7.8 \mathrm{ng} / \mathrm{mL}$ (target levels 5-15 ng/mL). Routine CSF analysis and immunoglobulin $\mathrm{G}$ index were normal, and there were no CSF oligoclonal bands. Laboratory investigations for viruses including CSF PCR-based analysis for JC virus,
Clinical/Scientific Notes

Epstein-Barr virus, herpes simplex virus, varicellazoster virus, cytomegalovirus, and other infections such as syphilis, tuberculosis, borreliosis, and mycoses in CSF were all negative. HIV serology was negative. A NGS gene panel (Fundación Galega de Medicina Xenómica, Santiago de Compostela, Spain) did not find pathogenic mutations in leukoencephalopathy-related genes. Antineuronal antibodies (anti-Hu, Yo, Ri amphiphysin, CRMP-5, Ma, voltage-gated potassium channel complex, NMDA receptor) and several autoantibodies were negative (antinuclear antibodies, anti-dsDNA, anti-histone, anti-Ro/SS-A, anti-La/SS-B, anti-PM$\mathrm{Scl}$, anti-RNP, anti-Sm, anti-CCP, antiphospholipid, systemic lupus erythematosus, anti-thyroid, cytoplasmic antineutrophil cytoplasmic antibodies, and perinuclear antineutrophil cytoplasmic antibodies).

The patient's symptoms worsened over the following weeks, and a brain biopsy was performed. Neuropathologic examination showed inflammatory demyelination with diffuse white matter myelin loss and relative preservation of axons. There was an associated perivascular T-lymphocyte predominant infiltration, white matter parenchymal macrophagic infiltrate, and prominent astrogliosis, with no evidence of tumor cells, abnormal inclusions, or vasculitic changes (figure, E-J).

Seven days after the biopsy, the patient received empirical treatment with IV methylprednisolone $1,000 \mathrm{mg}$ once daily for 3 days, without improvement. Hypothesizing that tacrolimus could have induced the leukoencephalopathy, it was discontinued and switched to everolimus. Follow-up MRI 6 weeks later showed the resolution of contrast enhancement, and no new lesions were seen. Over the following months, the patient's cognitive and behavioral symptoms improved dramatically. A mild cognitive impairment remained (MMSE 28/30). He is able to walk independently with a cane. A followup MRI performed 18 months after the brain biopsy showed a clear improvement of the leukoencephalopathy on T2/fluid-attenuated inversion recovery sequences, without complete resolution (figure, D).

Discussion. Tacrolimus revolutionized transplantation immunosuppressive therapy in the 1980s, but since then its use has been associated with a wide spectrum of neurotoxicity, ranging from mild tremors to white 

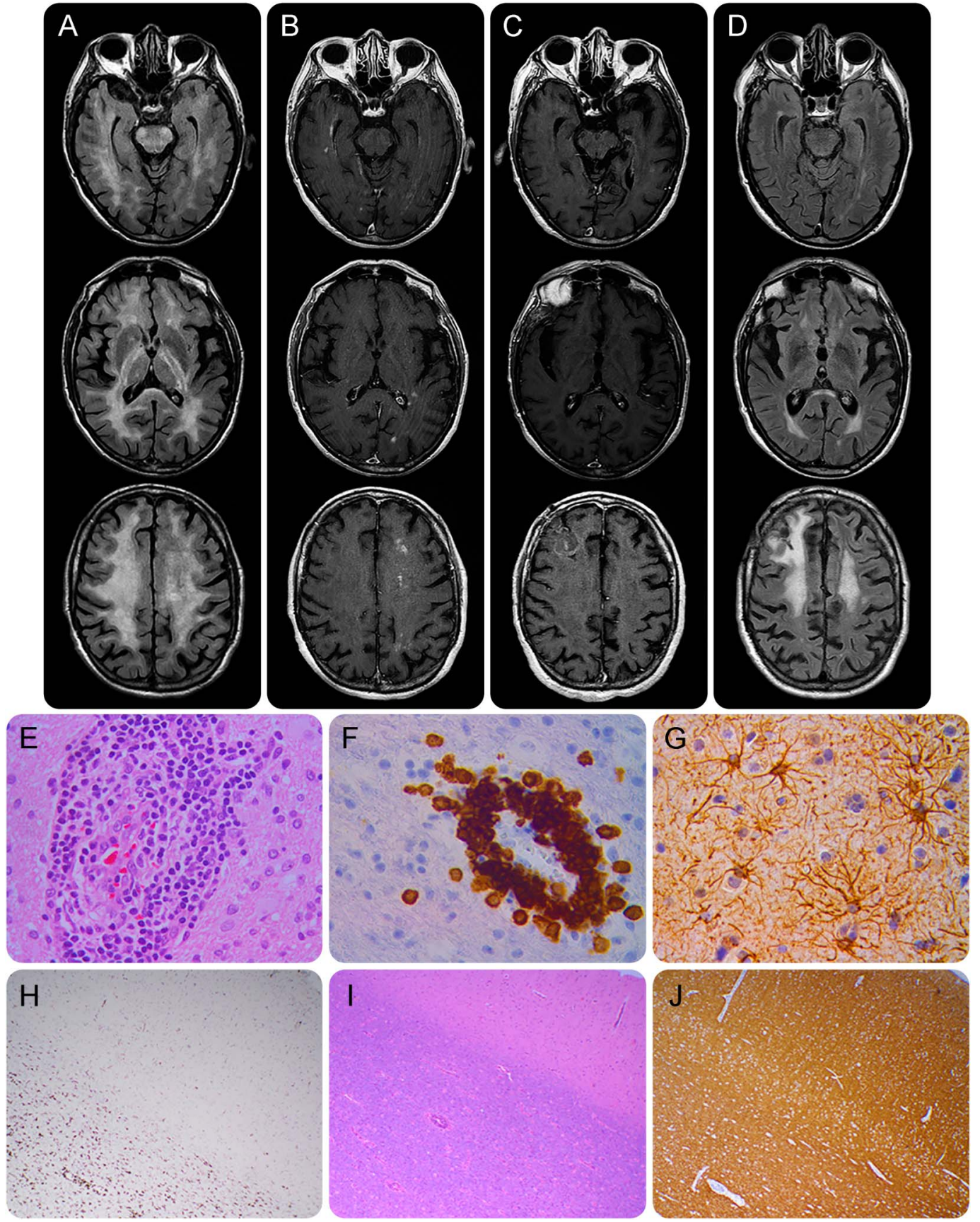

(A) Axial fluid-attenuated inversion recovery (FLAIR) and (B) enhanced T1-weighted MRI on admission show diffuse changes involving subcortical and deep white matter in both hemispheres and posterior fossa, with multiple subtle patchy areas of contrast enhancement. (C) MRI 6 weeks after discontinuing tacrolimus evidences resolution of contrast enhancement. Rests of hematoma at the biopsy site can also be seen. (D) Follow-up FLAIR MRI 18 months after tacrolimus withdrawal shows clear and partial leukoencephalopathy improvement. Brain biopsy specimens: (E) hematoxylin \& eosin staining sections reveal occasional perivascular inflammatory infiltrates $(\times 400)$; $(F)$ immunohistochemical staining confirms a $T$ lymphocyte (CD3-positive) predominance $(\times 400)$; $(G)$ white matter astrogliosis with enlarged astrocytic cell bodies shows a high immunoreactivity for glial fibrillary acidic protein $(\times 400)$. $(H)$ A large number of CD68-positive macrophages is also observed $(\times 40)$. (I) Luxol fast blue staining and $(\mathrm{J})$ neurofilament immunochemistry sections show a myelin-axonal dissociation with relative preservation of axons, suggestive of demyelination $(\times 40)$.

matter disease. ${ }^{1,2}$ Clinical features of tacrolimus-induced leukoencephalopathy include an acute onset with mild symptoms that progress rapidly to encephalopathy and seizures, similar to other forms of PRES. It has been described after most solid organ transplantations and varies in frequency from $0.8 \%$ to $6 \% .^{3,4}$ Most cases occur within the first month after transplantation, with only $2 \%$ arising after the first year, and liver 
transplant recipients seem to develop these lesions even earlier. ${ }^{4}$ Although not every study demonstrates a clear relation between the level of tacrolimus and the development of leukoencephalopathy, reducing the dose of tacrolimus or discontinuing the drug usually leads to a regression of symptoms. ${ }^{1,4}$ MRI usually reveals white matter damage predominantly in the posterior cerebral regions, and the few cases with pathologic description confirm areas of demyelination with sparing of axons, microglial activation and increased astrocytes within white matter, and a perivascular T-lymphocyte infiltration.,

Our patient showed several characteristics distinct from PRES caused by tacrolimus. We did not find in the literature any clinical description of slowly progressive cognitive decline similar to this case, and the clinical course was atypical, with a 10-year lag between the introduction of treatment and symptoms onset. We rule out a monophasic inflammatory demyelination syndrome because the long course of the illness and imaging features would be highly atypical. Clinical improvement began after tacrolimus discontinuation, suggesting a causal relationship with the drug, in the absence of alternative diagnoses. Brain biopsy revealed an active inflammatory demyelination, resembling the few cases reporting pathologic description of tacrolimus-related demyelination. ${ }^{2,5}$ These findings suggest that, although clinical presentation and neuroimaging findings are different, the underlying pathophysiology could be similar to acute forms of tacrolimus-induced white matter toxicity like PRES, and the late onset and gradually progressive symptoms could be related to the long-term, low-dose use of tacrolimus. The pathophysiology of tacrolimus-induced neurotoxicity remains unclear, and it may be multifactorial. In this case, some of the proposed mechanisms could be involved, like endothelial damage with blood-brain barrier disruption or T-cell dysregulation, ${ }^{2}$ a well-known side-effect of calcineurin inhibitors, related to other tacrolimus-induced autoimmune diseases.

Our case suggests that white matter damage caused by tacrolimus can have a slow onset and be seen years after its initiation and manifest as dementia. Follow-up in transplanted patients should include regular neurologic assessment since symptoms seem to be reversible after discontinuation of the drug.

From Hospital Universitario 12 de Octubre (D.B.-M., A.S.-D., P.C.-C., A.H.-L., A.R.-G., A.V.-G.); Instituto de Investigación Imas 12 (A.H.-L., A.R.-G., A.V.-G.); and Universidad Complutense de Madrid (A.H.-L., A.R.-G., A.V.-G.), Spain.

Author contributions: Diego Barragan-Martinez: study concept and design, drafting of the manuscript. Ana Simarro-Diaz: acquisition of data, drafting of the manuscript. Patricia Calleja-Castaño: acquisition of data. Aurelio Hernández-Lain: acquisition of data, critical revision of the manuscript for important intellectual content. Ana Ramos-González: acquisition of data, critical revision of the manuscript for important intellectual content. Alberto Villarejo-Galende: study concept and design, critical revision of the manuscript for important intellectual content.

Acknowledgment: The authors thank the patient and his family.

Study funding: No targeted funding.

Disclosure: D. Barragan-Martinez, A. Simarro-Diaz, P. CallejaCastaño, Aurelio Hernandez-Lain, and A. Ramos-Gonzalez report no disclosures. A. Villarejo-Galende received speaker honoraria from $K R K A, M S D$, and Hoffmann-La Roche; is an associate editor for Journal of Neurology and Neuroscience; and is an advisory board member for Neurologia. Go to Neurology.org/nn for full disclosure forms. The Article Processing Charge was paid by the Fundación para la investigación biomédica del hospital universitario 12 de Octubre.

This is an open access article distributed under the terms of the Creative Commons Attribution-NonCommercial-NoDerivatives License 4.0 (CC BY-NC-ND), which permits downloading and sharing the work provided it is properly cited. The work cannot be changed in any way or used commercially without permission from the journal.

Received October 8, 2016. Accepted in final form November 15, 2016.

Correspondence to Dr.Villarejo-Galende: avgalende@yahoo.es

1. Bechstein WO. Neurotoxicity of calcineurin inhibitors: impact and clinical management. Transpl Int 2000;13: 313-326.

2. Kim SH, Kim W, Lee KW, Hong EK, Kim HJ. Tumefactive demyelination, an uncommon form of tacrolimus neurotoxicity. Neurology 2011;76:672-674.

3. Vizzini G, Asaro M, Miraglia R, et al. Changing picture of central nervous system complications in liver transplant recipients. Liver Transpl 2011;17:1279-1285.

4. Singh N, Bonham A, Fukui M. Immunosuppressive-associated leukoencephalopathy in organ transplant recipients. Transplantation 2000;69:467-472.

5. Thyagarajan GK, Cobanoglu A, Johnston W. FK506-induced fulminant leukoencephalopathy after single-lung transplantation. Ann Thorac Surg 1997;64:1461-1464. 


\section{Neurology \\ Neuroimmunology \& Neuroinflammation}

Delayed tacrolimus leukoencephalopathy, a rare and reversible cause of dementia

Diego Barragán-Martínez, Ana Simarro-Díaz, Patricia Calleja-Castaño, et al.

Neurol Neuroimmunol Neuroinflamm 2017;4;

DOI 10.1212/NXI.0000000000000319

This information is current as of January 10, 2017

\section{Updated Information \& Services}

References

Subspecialty Collections

Permissions \& Licensing

Reprints including high resolution figures, can be found at:

http://nn.neurology.org/content/4/2/e319.full.html

This article cites 5 articles, 0 of which you can access for free at: http://nn.neurology.org/content/4/2/e319.full.html\#\#ref-list-1

This article, along with others on similar topics, appears in the following collection(s):

All Cognitive Disorders/Dementia

http://nn.neurology.org//cgi/collection/all_cognitive_disorders_dementi a

All Demyelinating disease (CNS)

http://nn.neurology.org//cgi/collection/all_demyelinating_disease_cns MRI

http://nn.neurology.org//cgi/collection/mri

Other toxicology

http://nn.neurology.org//cgi/collection/other_toxicology

Information about reproducing this article in parts (figures,tables) or in its entirety can be found online at:

http://nn.neurology.org/misc/about.xhtml\#permissions

Information about ordering reprints can be found online:

http://nn.neurology.org/misc/addir.xhtml\#reprintsus

Neurol Neuroimmunol Neuroinflamm is an official journal of the American Academy of Neurology.

Published since April 2014, it is an open-access, online-only, continuous publication journal. Copyright

Copyright (C) 2017 The Author(s). Published by Wolters Kluwer Health, Inc. on behalf of the American

Academy of Neurology. All rights reserved. Online ISSN: 2332-7812.

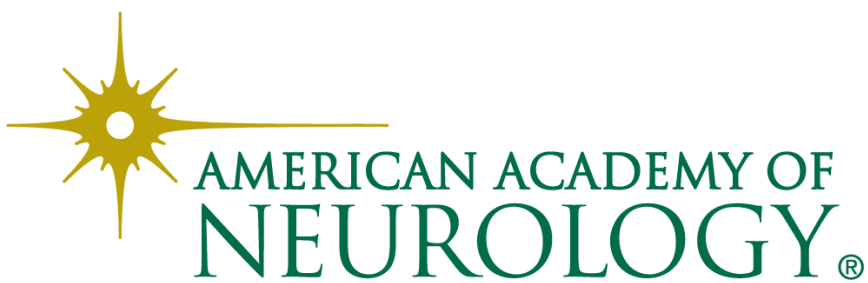

